\title{
Neuronal P2X7 Receptor: Involvement in Neuronal Physiology and Pathology
}

\author{
๑M. Teresa Miras-Portugal, ${ }^{1 *}$ Álvaro Sebastián-Serrano, ${ }^{1,2 *}$ Laura de Diego García, ${ }^{1,2}$ and ${ }^{\oplus}$ Miguel Díaz-Hernández ${ }^{1,2}$ \\ ${ }^{1}$ Department of Biochemistry and Molecular Biology, Veterinary School, Universidad Complutense de Madrid, 28040 Madrid, Spain, and ${ }^{2}$ Instituto de \\ Investigación Sanitaria del Hospital Clínico San Carlos, 28040 Madrid, Spain
}

The proposed presence of $\mathrm{P} 2 \mathrm{X} 7$ receptor $(\mathrm{P} 2 \mathrm{X} 7 \mathrm{R})$ in neurons has been the source of some contention. Initial studies suggested an absence of P2X7R mRNA in neurons, and the apparent nonspecificity of the antibodies used to identify P2X7R raised further doubts. However, subsequent studies using new pharmacological and biomolecular tools provided conclusive evidence supporting the existence of functional P2X7Rs in neurons. The P2X7 receptor has since been shown to play a leading role in multiple aspects of neuronal physiology, including axonal elongation and branching and neurotransmitter release. P2X7R has also been implicated in neuronal pathologies, in which it may influence neuronal survival. Together, this body of research suggests that P2X7R may constitute an important therapeutic target for a variety of neurological disorders.

\section{Introduction}

\section{Initial controversy regarding the presence of P2X7R} in neurons

$\mathrm{P} 2 \mathrm{X}$ receptors are ATP-gated cation channels consisting of three subunits, each of which contains two transmembrane domains joined by a cysteine-rich ectodomain. To date, seven distinct subunits (P2X1-7) have been cloned in mammalian cells. In contrast to other members of the P2X family, the P2X7 subunit has been only found in homomeric receptors (Burnstock et al., 2011). Specific characteristics of the $\mathrm{P} 2 \mathrm{X} 7$ receptor $(\mathrm{P} 2 \mathrm{X} 7 \mathrm{R})$ include its low sensitivity to ATP; its potentiation of the effects of ATP and the higher affinity agonist 2',3'-O-(4-benzoyl-4-benzoyl)-ATP (Bz-ATP) by reducing concentrations of extracellular calcium or magnesium (Surprenant et al., 1996); and its long intracellular carboxyterminal domain, which has been implicated in an additional channel dilation (Virginio et al., 1999b). In some peripheral cells, $\mathrm{P} 2 \mathrm{X} 7 \mathrm{R}$ stimulation is associated with wider pore opening $(>3$

\footnotetext{
Received Feb. 22, 2017; revised May 12, 2017; accepted May 16, 2017

This work was supported by Spanish Ministry of Science and Education BFU2012-31195 to M.D.-H. and BFU2014-53654-P to M.T.M.-P., and Universidad Complutense de Madrid-Santander Central Hispano Bank 911585-670 to M.D.-H. A.S.-S. was supported by Spanish Ministry of Science and Education Grant BFU2012-31195. L.d.D.G. received Universidad Complutense de Madrid predoctoral fellowship and was supervised by M.D.-H.

The authors declare no competing financial interests.

${ }^{*}$ M.T.M.-P. and A.S.-S. contributed equally to this work.

Correspondence should be addressed to Dr. Miguel Díaz-Hernández, Department of Biochemistry and Molecular Biology, Veterinary School, Universidad Complutense de Madrid, Avda. Puerta de Hierro S/N, 28040 Madrid, Spain. E-mail:migueldiaz@ucm.es.

Á. Sebastián-Serrano's present address: Instituto de Investigaciones Biomédicas "Alberto Sols," Consejo Superior de Investigaciones Científicas-Universidad Autónoma de Madrid, C/Arturo Duperier 4, Madrid 28029, Spain, and Centro de Investigación Biomédica en Red sobre Enfermedades Neurodegenerativas, Instituto de Salud Carlos III, C/ Valderrebollo, 5, 28031 Madrid, Spain.

DOI:10.1523/JNEUROSCI.3104-16.2017

Copyright $\odot 2017$ the authors $\quad 0270-6474 / 17 / 377063-10 \$ 15.00 / 0$
}

$\mathrm{nm}$ ), enabling the passage of molecules of up to $900 \mathrm{Da}$, such as the YO-PRO dye (Virginio et al., 1999a). Pore activation by $\mathrm{P} 2 \mathrm{X} 7 \mathrm{R}$ is thought to be mediated via a large receptor-signaling complex of cytoskeletal and integrin molecules (Wilson et al., 2002). Although this complex has been described in peripheral immune cells, its association with P2X7R in the CNS remains a matter of controversy, as discussed below (Kim et al., 2001).

The presence of P2X7R in immune and dendritic cells of hematopoietic lineage was widely accepted by the scientific community. However, initial studies describing the presence of this receptor in neurons were the subject of much debate (Sim et al., 2004; Anderson and Nedergaard, 2006). Two key issues accounted for the reticence to accept these findings. First, initial studies in rat brain using digoxigenin-labeled in situ hybridization studies indicated that P2X7R was present in ependymal cells in both the newborn and adult brains, but not in brain parenchyma (Collo et al., 1997). Second, when the antibodies most commonly used to detect P2X7R were tested in two putative knock-out mice (Solle et al., 2001; Sim et al., 2004), persistent neuronal immunostaining was still detected in both models. Although these two observations led researchers to question the initial studies that pointed to the presence of this receptor in neurons (Deuchars et al., 2001; Armstrong et al., 2002; Sperlágh et al., 2002; Miras-Portugal et al., 2003; Atkinson et al., 2004), both have been refuted in recent years. A more sensitive in situ hybridization technique using ${ }^{35} \mathrm{~S}$-labeled cRNA revealed that $\mathrm{P} 2 \mathrm{X} 7 \mathrm{R}$ mRNA is widely distributed in the adult rat brain. Double-staining demonstrated a P2X7 mRNA signal in NeuNpositive neurons, OX-42-positive microglia, and CNPase-positive oligodendrocytes, although, surprisingly, no signal was detected in GFAP-positive astrocytes (Yu et al., 2008). P2X7R mRNA was 


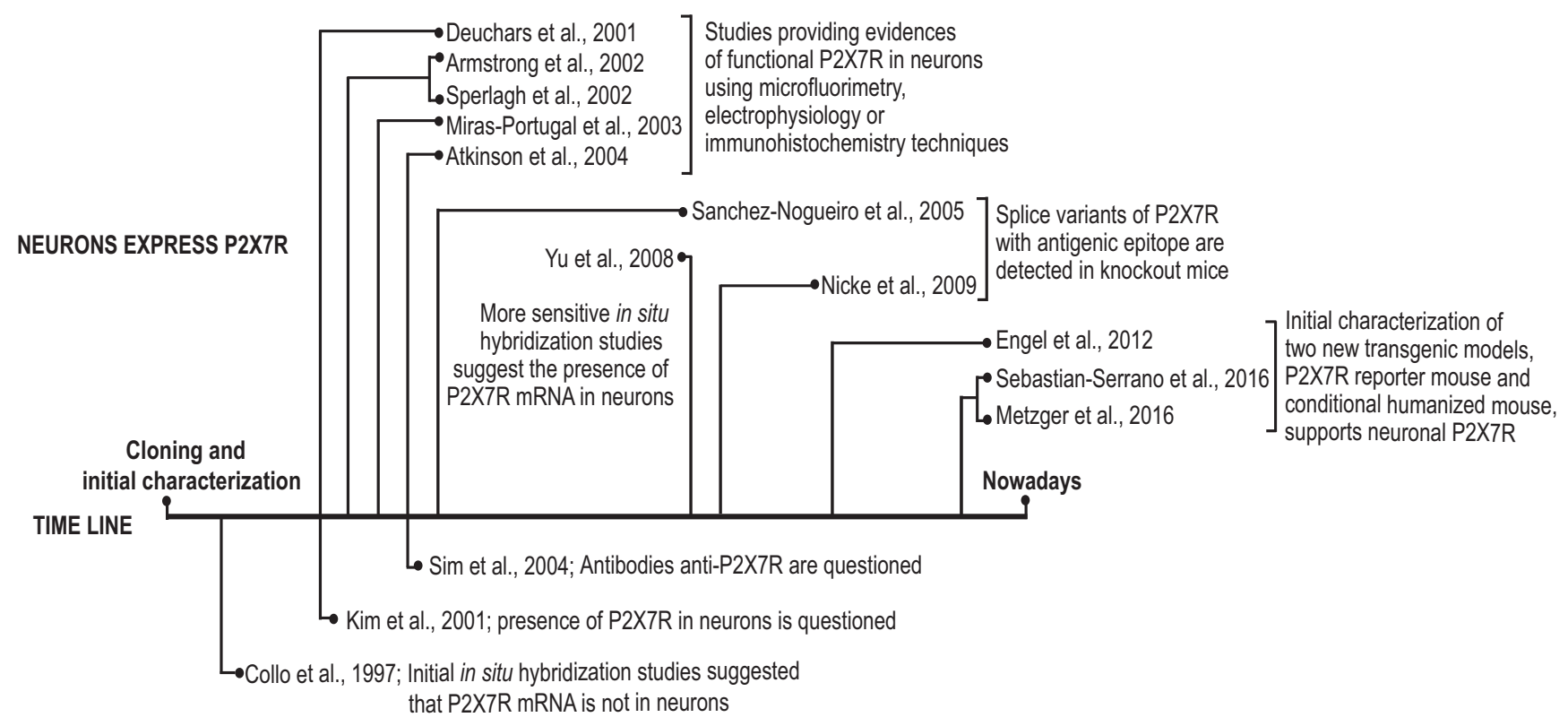

NEURONS DO NOT EXPRESS P2X7R

Figure 1. Schematic illustration summarizing the initial controversy regarding the presence of P2X7R in neurons.

subsequently detected in distinct neural lineages, as described below. The lack of neuron-specific staining attributed to antibodies against P2X7R was explained when several splice variants of $\mathrm{P} 2 \mathrm{X} 7 \mathrm{R}$ that retain the antigenic epitope were detected in knockout mice (Sánchez-Nogueiro et al., 2005; Nicke et al., 2009). These studies showed that both models should be considered deficient in or hypomorphic for P2X7R, but not bona fide knockout models. Two new mice models have been recently generated for the in vivo study of $\mathrm{P} 2 \mathrm{X} 7 \mathrm{R}$. The first is a knockin mouse that expresses a humanized P2X7R under the control of the endogenous murine regulatory elements and sensitive to Cre recombinasemediated inactivation (Metzger et al., 2017), whereas the second mouse model expresses the EGFP immediately downstream of the P2X7 mouse promoter (Engel et al., 2012; García-Huerta et al., 2012; Sebastián-Serrano et al., 2016). Initial analysis of the first model has confirmed the presence of P2X7R in glutamatergic pyramidal neurons of the CA3 hippocampal area (Metzger et al., 2017). In addition, after Cre-dependent disruption of the P2RX7 gene, expression of P2X7 receptor, including all its known splice variants, was not detected in brain of these mice (Metzger et al., 2017). In the case of the second model, selective agonists and antagonists of P2X7R have been used to demonstrate the presence of functional P2X7R in EGFP-positive hippocampal neurons (Engel et al., 2012; Sebastián-Serrano et al., 2016). Studies collected in this section providing evidence for and against the presence of P2X7R in neurons are summarized in Figure 1.

In this review, we discuss the evidence for neuronal expression of P2X7R collected from a broad range of in vitro and in vivo models, ranging from simple cell lines to complex mouse models of neurological disorders.

\section{P2X7R expression in immortalized neuronal cell lines}

Immortalized neuronal cell lines (NCLs) are among the simplest biological systems used to evaluate the presence of P2X7R in neuronal cells. P2X7R mRNA and protein have both been detected in diverse human and murine NCLs (Larsson et al., 2002; Jun et al., 2007; Gómez-Villafuertes et al., 2009; Orellano et al.,
2010; Chao et al., 2014; Amoroso et al., 2015). Stimulation of nondifferentiated neuronal human SH-SY5Y cells (Larsson et al., 2002) or murine neuroblastoma (N2A cells) (Gómez-Villafuertes et al., 2009) with ATP or Bz-ATP increases the intracellular calcium concentration, as detected using FURA-2 dye, and evokes inward currents in whole-cell configuration, as recorded by patch-clamp techniques. Both events are sensitive to the presence of divalent cations in the extracellular medium (Surprenant et al., 1996), and are inhibited by selective P2X7R antagonists, including KN-62 (Gargett and Wiley, 1997), Brilliant Blue G (BBG) (Jiang et al., 2000), and A438079 (Nelson et al., 2006). Moreover, pharmacological inhibition or selective knockdown of P2X7R by small hairpin RNA interference favors neuronal differentiation of N2A cells by increasing neurite formation (Gómez-Villafuertes et al., 2009). Conversely, retinoic acid-induced neuronal differentiation of SH-SY5Y decreases, but does not abolish, P2X7R expression, thus protecting differentiated cells from extracellular nucleotide-induced neuronal death (Orellano et al., 2010). These observations suggest that P2X7R plays a key role in the differentiation of NCLs. The involvement of P2X7R in cell cycle arrest, which is required to induce neuronal differentiation, has also been investigated. Both the selective P2X7R antagonist A740003 (Honore et al., 2006) and the negative modulator AZ10606120 (Michel et al., 2008) reduce cellular proliferation in a human neuroblastoma cell line (ACN) and in the murine neuroblastoma cell line (N2A), and decrease the size of the tumors induced by subcutaneous inoculation of ACN or N2A cells in mice (Amoroso et al., 2015).

In addition to neuroblastoma cell lines, functional P2X7R is also expressed in immortalized dopaminergic neurons (SN4741 cells) derived from the substantia nigra of transgenic mouse embryos. Interestingly, the sustained activation of P2X7R by high ATP concentrations induces the death of SN4741 cells, an effect prevented by both KN-62 and selective siRNA knockdown of P2X7R (Jun et al., 2007). Similarly, inhibition of P2X7R attenuates neuronal death induced by 6-hydroxydopamine in SH-SY5Y cells (Carmo et al., 2014) and ATP-induced death in NG108-15 
cells that have differentiated into neurons (Chao et al., 2014). Although the aforementioned studies suggest the presence of P2X7R in neuronal cells, they were all conducted using immortalized cell lines, and thus do not constitute definitive evidence of the presence of this receptor in native neurons. Nevertheless, and as discussed below, independent groups have provided additional evidence supporting the presence of P2X7R in neurons using primary neuronal cultures from different brain regions.

\section{P2X7R in neural progenitors and role in neuronal fate}

In the adult CNS, new neurons arise from neural stem cells, a quiescent cell population that resides in the neurogenic niche of the subgranular zone of the hippocampal dentate gyrus and the subventricular zone of the lateral ventricle. Throughout neurogenesis, neural stem cells lose their self-renewal capacity and transform into neuronal progenitor cells (NPCs). These cells have a limited proliferative capacity and evolve to neuroblasts before generating new neurons (Gonçalves et al., 2016). The presence of functional P2X7R has been described in embryonic stem cells (ESCs), neuron-like human ESC-derived neural progenitors, human NPCs, and NPCs isolated from the subventricular zone of adult mice or the striatum of embryonic mice (Delarasse et al., 2009; Thompson et al., 2012; Forostyak et al., 2013; Messemer et al., 2013; Glaser et al., 2014; Lovelace et al., 2015). These studies used similar experimental approaches to those used in the aforementioned immortalized cell line studies, including detection of P2X7R mRNA and protein, electrophysiological recording, measurement of changes in intracellular calcium levels induced by ATP or Bz-ATP in the presence or absence of selective P2X7R antagonists, or specific siRNA against P2X7R. In ESCs and NPCs, P2X7R appears to mediate contrasting effects. While acute P2X7R activation with high ATP concentrations induces cell death that is detectable by 3-(4,5-dimethylthiazol-2yl)-2,5-diphenyltetrazolium bromide assay or by measuring lactate dehydrogenase release (Delarasse et al., 2009; Thompson et al., 2012; Messemer et al., 2013), sustained receptor activation in response to more moderated ligand concentrations accelerates cell cycle entry (Tsao et al., 2013; Glaser et al., 2014). In agreement with the long-term effects attributed to P2X7R, and analogous to the finding reported in SH-SY5Y cells, the induction of neuronal differentiation in embryonic ESCs by retinoic acid significantly attenuates P2X7R expression in these cells (Glaser et al., 2014). Moreover, pharmacological P2X7R inhibition promotes the expression of neuronal markers in ESCs (Glaser et al., 2014). In line with findings obtained in cell culture, electrophysiological studies using slices from EGFP-nestin mice (Messemer et al., 2013) and in situ hybridization assays combined with immunohistological techniques using neuronal markers in embryonic rats (Tsao et al., 2013) have confirmed the presence of functional P2X7Rs in NPCs from the subventricular zone and subgranular zone in both species. In addition, the in vivo studies using thymidine analogs to label new hippocampal cells revealed that both postnatal and adult P2X7 hypomorphic mice present an altered proliferation in the subgranular zone (Csölle et al., 2013; Sebastián-Serrano et al., 2016). We can conclude from these reports that, although P2X7R expression decreases throughout neurogenesis, it persists in NPCs and neuroblasts, probably to regulate neurogenesis in suboptimal conditions. In support of this hypothesis, the transcription factor Sp1, which positively regulates P2X7R expression (García-Huerta et al., 2012; Gómez-Villafuertes et al., 2015) and is essential for early embryonic development, loses relevance during cell growth and differentiation (Marin et al., 1997).

\section{P2X7R regulates axonal growth and branching}

Axonal growth and guidance are critical aspects of neuroblast differentiation to neurons. Once neurons reach their correct position, they initiate elongation of their axons toward their target, generating the specific neuronal circuits found in the mature brain (da Silva and Dotti, 2002). Initial studies performed in neural tube explants from 12-d-old rat embryos suggested that ATP acts as a negative modulator of neurite extension (Cheung et al., 2005). Studies of rat thoracolumbar sympathetic neurons revealed the expression of P2X7R mRNA and protein along the axons of these neurons (Allgaier et al., 2004). However, in that study, ATP-induced increases in axonal calcium concentrations were neither sensitive to BBG nor lower than those induced by equivalent concentrations of Bz-ATP, suggesting that these axons do not express functional P2X7Rs. Another study using mixed hippocampal neuronal-astrocytic cell cultures found that ATPand Bz-ATP-induced elevations in intracellular $\mathrm{Ca}^{2+}$ concentration in neuronal axonal/dendritic extensions occur only in those that are in close physical contact with the underlying astroglial carpet (Rubini et al., 2014). However, because of the limited resolution of the technique used, the authors were unable to determine whether the calcium increase occurred in axonal/dendritic processes or in the underlying glial cells. Our research group has shown that, in pure cultures of hippocampal neurons seeded at low density, in which the differentiation of a single neuron can be monitored and glial contamination is absent, a pulse of ATP induces a focal increase in the intracellular $\mathrm{Ca}^{2+}$ concentration in the axonal growth cone (Díaz-Hernández et al., 2008). We found that the $\mathrm{Ca}^{2+}$ wave generated only reached the distal-most region of the axon but did not spread to the rest of axon or the somatic compartment. This focal $\mathrm{Ca}^{2+}$ influx correlated with changes in growth cone morphology, a process mediated by focal adhesion kinase, which is activated by calcium-calmodulin kinase II. Using pharmacological and biomolecular tools, we confirmed the involvement of P2X7R in these alterations. Interestingly, we found that specific P2X7R antagonists induce a significant increase in axonal length and branching (Díaz-Hernández et al., 2008). In agreement with our observations, decreases in intracellular $\mathrm{Ca}^{2+}$ levels in axonal growth cones accelerate axonal elongation (Gomez and Spitzer, 1999). ADP, acting via P2Y1R and P2Y13R, has also been shown to regulate the inhibitory effect of P2X7R on axonal growth and branching (del Puerto et al., 2012).

\section{Tissue-nonspecific alkaline phosphatase (TNAP) modulates axonal growth via $\mathbf{P} 2 X 7 \mathrm{R}$}

During the first few days in culture, extracellular ATP levels in hippocampal neurons were found to be considerably reduced (Díez-Zaera et al., 2011). This reduction is correlated with a significant increase in TNAP activity, especially at the axonal growth cone. It is important to note that, during the first $3 \mathrm{~d}$ of culture, one of the neurites emerges from the cell body to become the axon. As expected, pharmacological inhibition or genetic depletion of the TNAP over this period of time resulted in higher levels of extracellular ATP and inhibition of axonal growth and branching (Díez-Zaera et al., 2011). The authors found that neither activation nor inhibition of adenosine receptors influenced axonal growth, indicating that adenosine, the principal product generated by extracellular hydrolysis of ATP by TNAP, was not involved in this process. These results suggest a close functional relationship between P2X7R and TNAP, whereby TNAP induces axonal elongation by hydrolyzing ATP in close proximity to the receptors, thus preventing P2X7R activation. Reinforcing this view, P2X7R inhibition reduced TNAP expres- 
sion, whereas the addition of exogenous TNAP enhanced P2X7R expression (Díez-Zaera et al., 2011). In agreement with those findings, a recent study reported that seizures associated with hypophosphatemia, a severe disease provoked by a hypomorphic mutation of TNAP, were linked to neurodevelopmental alterations caused by partial dysregulation of P2X7R expression (Sebastián-Serrano et al., 2016). In the early postnatal period, these authors showed that TNAP-knock-out mice possess shorter callosal axonal projections than their wild-type littermates. This deficiency was prevented by selective knockdown of P2X7R in cortical neurons after in utero electroporation at the embryonic stage (Sebastián-Serrano et al., 2016), thus demonstrating that this is a cellular autonomous process. Support for the involvement of P2X7R in axonal elongation and branching was obtained following in vivo administration of BBG to wild-type mice, which induced a significant increase in the thickness of the densely packed hippocampal CA3 pyramidal layer proximal to dentate gyrus. In deficient P2X7 mice, a similar phenotype was also observed that was attributed to the invasion of axonal fibers that become intercalated among of the nuclei of the CA3 pyramidal layer proximal to dentate gyrus (Sebastián-Serrano et al., 2016). In line with these findings, distal axonal regeneration toward synaptic areas was observed in adult rats treated with BBG for $2 \mathrm{~d}$ after controlled optic nerve crush (Ridderström and Ohlsson, 2014).

\section{Presynaptic P2X7R regulates neurotransmitter release}

After the axonal growth cone reaches its target and establishes a functional synaptic contact, P2X7R expressed in the growth cone remains present at the presynaptic element (Deuchars et al., 2001; Armstrong et al., 2002; Sperlágh et al., 2002; Miras-Portugal et al., 2003; Atkinson et al., 2004; Ireland et al., 2004; Moores et al., 2005; Wirkner et al., 2005; Alloisio et al., 2008; Cho et al., 2010; Cuadra et al., 2014; P.A. Zhang et al., 2017). Many of the aforementioned studies describing the presence of presynaptic P2X7R were performed in isolated synaptic terminals. These preparations can be used to directly analyze events in presynaptic elements because they do not contain glial, microglial, or oligodendrocyte cells, or postsynaptic elements (Díaz-Hernández et al., 2002; Marcoli et al., 2008), and contain a high percentage (>95\%) of nerve endings positively identified with antibodies against synaptophysin protein. Because in these studies the astrocytic marker used was the GFAP, which is not present at the fine presynaptic processes of astrocytes, the presence of P2X7R in glia cannot be ruled out. However, and although in recent years several research groups have reported the presence of some synaptic proteins in astrocytes, synaptophysin has not been detected in glial cells (Sahlender et al., 2014; Verkhratsky et al., 2016). P2X7R has been detected in isolated nerve terminals from the cortex (Alloisio et al., 2008; Marcoli et al., 2008), striatum (Díaz-Hernández et al., 2009), midbrain (Miras-Portugal et al., 2003), hippocampus (Armstrong et al., 2002; Engel et al., 2012; Sebastián-Serrano et al., 2016), and cerebellum (Sánchez-Nogueiro et al., 2005). In these nerve endings, pulses of ATP or Bz-ATP induce intrasynaptosomal calcium increases that are sensitive to extracellular divalent cation concentration and to specific P2X7R antagonists, such as A438079, KN-62, and BBG (Miras-Portugal et al., 2003; Sánchez-Nogueiro et al., 2005; Alloisio et al., 2008; Marcoli et al., 2008). In good agreement, in isolated neurohypophysial terminals, the large size of which allows for electrophysiological analyses, ATP was shown to induce inwards currents that are sensitive to divalent cations and are diminished by the selective P2X7R antagonists AZ10606120 and BBG (Cuadra et al., 2014). Because the vesicular release of neurotransmitters is a direct consequence of increased calcium levels in nerve terminals, subsequent works studied the involvement of P2X7R in this event. Activation of presynaptic P2X7R was found to induce glutamate release in the cortex, cerebellum, and hippocampus (Sperlágh et al., 2002; Sánchez-Nogueiro et al., 2005; Alloisio et al., 2008; León et al., 2008; Marcoli et al., 2008; Cervetto et al., 2012), GABA release in the hippocampus (Sperlágh et al., 2002; Wirkner et al., 2005), and arginine-vasopressin release in the hypothalamic-neurohypophysial system (Cuadra et al., 2014). Moreover, P2X7R activation was shown to promote destaining of nerve terminals previously loaded with the FM1-43 dye (Deuchars et al., 2001; León et al., 2008). Exocytotic release induced by P2X7R has also been confirmed using total internal reflection fluorescence microscopy (Gutiérrez-Martín et al., 2011). In those experiments, P2X7R stimulation induced both an increase in near membrane $\mathrm{Ca}^{2+}$ concentration and the exocytosis of fluorescence-labeled vesicles. Furthermore, P2X7R activation was shown to affect vesicle motion in all directions, implicating this receptor in the control of the early stages (docking and priming) of the secretory pathway (Gutiérrez-Martín et al., 2011). In line with these observations, P2X7R activation was shown to induce phosphorylation of synapsin-I, resulting in its dissociation from synaptic vesicles and promoting vesicle mobilization and fusion with the plasma membrane (León et al., 2008). Because prolonged stimulation of P2X7R has been proposed to generate pores permeable to molecules of up to $900 \mathrm{Da}$ (Surprenant et al., 1996), it was hypothesized that P2X7R-mediated neurotransmitter release may occur via the pore, as opposed to a vesicular release mechanism. However, studies using cell-impermeable dyes, such us YO-PRO-1 (629 Da), have shown that activation of neuronal $\mathrm{P} 2 \mathrm{X} 7 \mathrm{R}$ does not induce YO-PRO-1 uptake in neurons, at least in nonpathological conditions (Deuchars et al., 2001; Armstrong et al., 2002; Moores et al., 2005; León et al., 2008).

Electrophysiological recording of evoked and spontaneous miniature EPSCs (mEPSCs) has provided further indirect evidence supporting the presynaptic presence of P2X7R (Ireland et al., 2004; Cho et al., 2010; Khakpay et al., 2010; P.A. Zhang et al., 2017). Because the EPSCs are blocked by selective glutamatergic receptor antagonists CNQX and AP-5, it was suggested that glutamate is the neurotransmitter involved in these currents. In this context, alterations in frequency or amplitude induced by Bz-ATP may be interpreted as a regulatory effect of presynaptic P2X7R on glutamate release. In accordance with this view, the stimulation of isolated immature hilar neurons with Bz-ATP was shown to increase the frequency of spontaneous EPSCs (sEPSC), an effect blocked by BBG (Cho et al., 2010). Similar effects on EPSCs were observed in mouse brain slices containing the hypoglossal nucleus (Ireland et al., 2004). Bz-ATP was also found to enhance the frequency of sEPSCs in rat brain slices containing the locus ceruleus. However, in the latter case, the effect of Bz-ATP was blocked by fluorocitric acid and D-aminoadipic acid, both putative toxins of astrocytes, thus calling in question the involvement of presynaptic P2X7R in this phenomenon (Khakpay et al., 2010). Based on P2X7R activation in astrocytes induces glutamate release, it was suggested that astrocytes and not neurons were the source of extracellular glutamate responsible for sEPSC potentiation (Khakpay et al., 2010). However, the exclusively astrocytic causality suggested by this study was contradicted by two important findings indicating that fluorocitric acid caused acute axonal dystrophy (Koenig, 1969), and that D-aminoadipic acid caused toxicity of mitotic cells (Brown and Kretzschmar, 1998). Moreover, the results of a recent study using slices of rat insular 


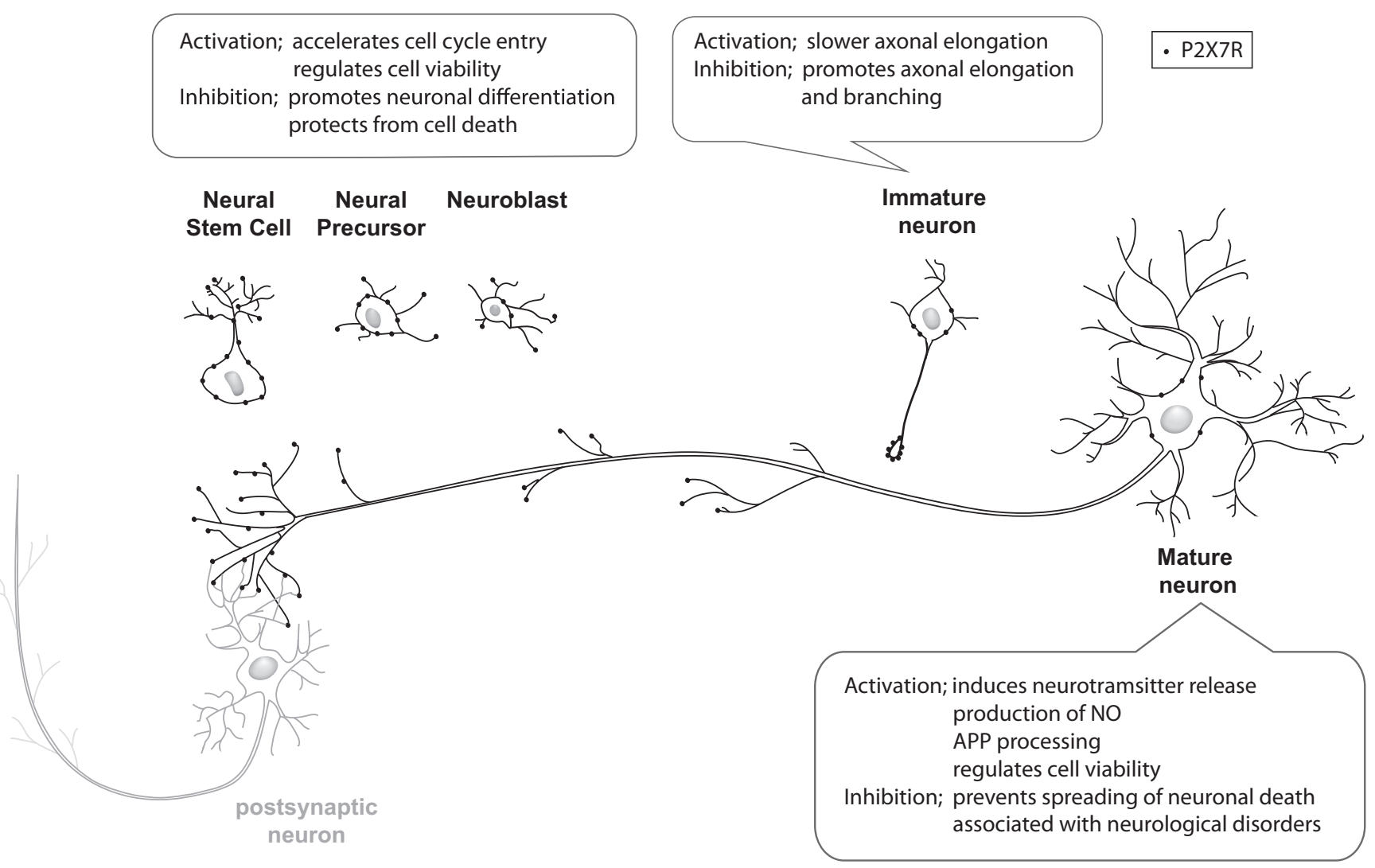

Figure 2. Schematic illustration summarizing the role that P2X7R plays in neuronal physiology.

cortex, in which P2X7R mRNA and protein were detected in synaptic terminals, demonstrated that activation of presynaptic P2X7Rs increased the frequency of sEPSCs and mEPSCs (P.A. Zhang et al., 2017). Those authors found that increases in sEPSCs and mEPSCs were prevented by pretreatment of slices with A438079. Moreover, BBG was found to also reverse the increases in sEPSC and mEPSC frequency induced by neonatal maternal deprivation in rats (P.A. Zhang et al., 2017). Finally, supporting the existence of a close relationship between nicotinic and P2X receptors at the presynaptic level (Díaz-Hernández et al., 2002, 2004), agonists of the $\alpha 7$ nicotinic receptor potentiate glutamate release from glutamatergic terminals in the rat neocortex in response to P2X7R activation, and nicotine-induced glutamate release is potentiated by P2X7R activation (Patti et al., 2006).

\section{P2X7R in hippocampal neurons}

Although P2X7R is widely expressed in brain, particularly high expression levels are observed in the hippocampus (Armstrong et al., 2002; Sperlágh et al., 2002; Engel et al., 2012; Sebastián-Serrano et al., 2016). The presence of functional $\mathrm{P} 2 \mathrm{X} 7 \mathrm{Rs}$ in this region was first described in the presynaptic terminals of mossy fiber in the rat (Armstrong et al., 2002). Subsequent studies revealed the presence of $\mathrm{P} 2 \mathrm{X} 7 \mathrm{R} \mathrm{mRNA}$ and protein in excitatory nerve terminals of the rat hippocampus (Sperlágh et al., 2002), and colocalization of P2X7R with the vesicular glutamate transporter 1 in the dentate gyrus and CA3 area (Atkinson et al., 2004). Functional studies demonstrated that P2X7R activation regulates the release of glutamate and subsequent GABA release (Sperlágh et al., 2002). In line with the idea of P2X7Rinduced GABA release, P2X7R activation was proposed to depress mossy fiber-CA3 synaptic transmission through the activation of p38 MAP kinase (Armstrong et al., 2002). The involvement of p38 MAP kinase in intracellular signaling pathways activated by presynaptic P2X7Rs was confirmed when a selective p38 MAP kinase inhibitor was shown to significantly attenuate P2X7R-induced glutamate release in mouse hippocampal slices (Papp et al., 2007). Although the synaptic depression induced by Bz-ATP was initially attributed to the activation of presynaptic P2X7 receptors (Armstrong et al., 2002), subsequent studies suggested that this inhibitory effect was caused by adenosine receptor activation. In this scenario, the adenosine mediating this effect would be derived from the ectonucleotidase-mediated enzymatic hydrolysis of Bz-ATP to Bz-adenosine, which is finally hetero-exchanged for cellular adenosine via the nucleoside transporter (Kukley et al., 2004). This hypothesis was based on the fact that the effects of Bz-ATP were reversed by 8-cyclopentyl-1,3dipropylxanthine, a selective antagonist of the adenosine A1 receptor. However, other research groups found no involvement of A1 receptors in the release of glutamate (Marcoli et al., 2008) or GABA (Wirkner et al., 2005), or in neuronal nitric oxide production (Codocedo et al., 2013) induced by hippocampal P2X7R activation. Moreover, the increase in sEPSC frequency induced by $\mathrm{P} 2 \mathrm{X} 7 \mathrm{R}$ activation in mechanically isolated immature hilar neurons was unaffected by 8 -cyclopentyl-1,3-dipropylxanthine (Cho et al., 2010). Interestingly, overexpression of the P2X7R in brain slices containing hippocampus was found to decrease both current amplitude and intrinsic neuronal excitability, whereas P2X7R inhibition had the opposite effect (del Puerto et al., 2015). This phenomenon was shown to be linked to the modulatory action of P2X7R on the axon initial segment; P2X7R regulates expression of the structural protein ankyrin $\mathrm{G}$ and the density of voltage-gated sodium channels in the axon initial segment 
via a mechanism involving calpain activation (del Puerto et al., 2015). Summarizing, although initially it was suggested that effects attributed to the P2X7R in hippocampal neurons might be due to adenosine receptor activation caused by extracellular hydrolysis of adenine nucleotides, later studies have ruled out this hypothesis.

\section{P2X7R in the neuronal somatodendritic compartment}

In addition to its expression in the presynaptic compartment, functional P2X7 receptor expression has been detected in the neuronal somatodendritic compartment. Somatic electrical responses and $\mathrm{Ca}^{2+}$ influx induced by ATP and Bz-ATP were shown to be blocked by P2X7R antagonists in primary cortical neuron cultures (Díaz-Hernández et al., 2009; Arbeloa et al., 2012; Nishida et al., 2012; Ohishi et al., 2016), primary cerebellar granular neuron cultures (Sánchez-Nogueiro et al., 2014), and brain slices containing the cortex (Arbeloa et al., 2012) or hippocampus (del Puerto et al., 2015; Sebastián-Serrano et al., 2016). Interestingly, in spinal cord slices, the whole-cell patch-clamp recording from substantia gelatinosa revealed that Bz-ATP triggered inward currents in both neurons and astrocytes (Ficker et al., 2014). The sensitivity of these currents to divalent cations and A438079 suggested the involvement of P2X7R. However, the marked attenuation of Bz-ATP-induced currents in neurons, but not in astrocytes, caused by the combination of AMPA, kainate, GABA, and glycine receptor antagonists suggested that the currents observed in neurons were due to Bz-ATP-induced glutamate release in astrocytes (Ficker et al., 2014). Nonetheless, given that this mixture of antagonists did not abolish Bz-ATP-induced neuronal currents, the presence of functional P2X7 receptors in neurons cannot be ruled out, particularly in light of findings demonstrating that neuronal nitric oxide production induced by the P2X7R activation is independent of glutamate receptor activation (Codocedo et al., 2013). In this same line, it was also reported that inhibition of neuronal P2X7R decreases the glycogen synthase kinase 3 activity, increasing the proteolytic processing of APP through an increase in $\alpha$-secretase activity (Díaz-Hernández et al., 2012). Finally, a recent study using EGFP-expressing retroviruses and biochemical approaches has demonstrated that granule neurons in the hippocampal dentate gyrus from postnatal P2X7 hypomorphic mice displayed altered synaptogenesis and a dendrite branching, thus suggesting that this receptor plays a key role in the somatodendritic compartment development (Sebastián-Serrano et al., 2016).

\section{Role of P2X7R in neuronal diseases}

Although P2X7R plays an important role in both neuronal differentiation and neuronal physiology by regulating axonal elongation and synaptic functionality, respectively, its role changes radically in pathological conditions. In response to initial insults or a variety of events that can compromise cell integrity, the large amount of ATP contained in the cytosolic compartment can reach the closest brain parenchyma (Burnstock et al., 2011). Observations in NCLs suggest that, in this pathological scenario, acute activation of P2X7R by high ATP concentrations induces cell death, promoting the subsequent spread of neuronal death. Consistent with this hypothesis, acute P2X7R activation by high concentrations of ATP induces neuronal death in pure cortical neuron cultures from mouse or rat, an effect prevented by selective P2X7R antagonists (Nishida et al., 2012; Ohishi et al., 2016). The molecular mechanism underlying this neuronal death involves mitochondrial dysfunction, as well as activation of caspase- 3 and apoptosis-inducing factor (Nishida et al., 2012). Similarly, acute stimulation of P2X7R by high ATP concentrations triggers apoptosis in cultured avian retinal neurons (Anccasi et al., 2013). However, in this study, the toxic effect was only observed in mixed astrocytic and neuronal cultures, and not in purified neuronal or astrocyte cultures. That ATP stimulates the accumulation of extracellular glutamate in astrocytes, but not in neuronal cultures, suggests a role of glutamate receptors in neuronal death (Anccasi et al., 2013). However, in cultures of pure cortical neurons from two different mouse strains, in which glial contamination is absent, acute activation of P2X7R by high concentrations of ATP induces caspase-dependent apoptotic cell death (Ohishi et al., 2016). Interestingly, when neurons are cocultured with astrocytes, a significant increase in ATP-induced neuronal death is detected. On the other hand, sustained P2X7R stimulation with low Bz-ATP concentrations induces caspase-mediated apoptosis in both rat retinal ganglion cells and cultured motor neurons isolated from the rat spinal cord, an effect blocked by P2X7R antagonists (X. Zhang et al., 2005; Gandelman et al., 2013). Interestingly, although some studies have postulated that ATPmediated neuronal death is dependent upon pore formation (Nishida et al., 2012; Anccasi et al., 2013), others suggest that this mechanism is not necessarily involved in ATP-induced neuronal death (X. Zhang et al., 2005; Gandelman et al., 2013). Supporting the neurotoxic effect attributed to $\mathrm{P} 2 \mathrm{X} 7 \mathrm{R}$, prolonged in vivo administration of P2X7R antagonists attenuates both neuronal cell death and pathological behavioral alterations in a range of animal models of neuronal diseases, including Huntington's disease (Díaz-Hernández et al., 2009), Parkinson's disease (Carmo et al., 2014; Wang et al., 2017), Alzheimer's disease (Díaz-Hernández et al., 2012; Chen et al., 2014; Irwin et al., 2016), epilepsy (JimenezPacheco et al., 2016), status epilepticus (Engel et al., 2012), and hypophosphatasia-associated seizures (Sebastián-Serrano et al., 2016), as well as in animal models of ischemia-induced brain damage (Arbeloa et al., 2012; Chen et al., 2013; Maraula et al., 2014) or traumatic spinal cord injury (Peng et al., 2009).

In conclusion, this review discusses how recent studies using new pharmacological and biomolecular tools, including new animal models, have helped to clarify initial doubts about neuronal expression of functional P2X7R. As it is summarized in Figure 2, these studies have provided evidence that $\mathrm{P} 2 \mathrm{X} 7 \mathrm{R}$ participates in neuronal differentiation and neuronal physiology by regulating axonal growth and presynaptic neurotransmitter release. However, in pathological conditions, this receptor may contribute to spread of neuronal cell death.

Response from Dual Perspectives Companion AuthorsPeter Illes, Tahir Muhammad Khan, and Patrizia Rubini

We enjoyed reading the article by Díaz-Hernández and coworkers presenting a strong case for the existence of neuronal P2X7 receptors (P2X7Rs). However, we still think that in most, if not all, cases in multicellular compartments of the central and peripheral nervous system, P2X7Rs are localized at astrocytes and microglia, and the resulting effects at neurons are indirect.

Despite the convincing argumentation of our opponents, we tend to question a number of sections of their review, among others as follows: 
1. Díaz-Hernández and coworkers report on data confirming the presence of P2X7R-mRNA in astrocyte-like neural progenitor cells and refer to studies on neuronal cell lines, in which P2X7R-mRNA decreases in the course of neuronal differentiation. Despite their intention, this appears to be an argument against the persistence of P2X7Rs in early postnatal and especially mature life, when the message for this mRNA is present in low amounts but probably does not code for the functional protein.

2. They write that pinched-off synaptic terminals (synaptosomes) are astrocyte-free because $>95 \%$ of these synaptosomes are immunopositive for the exclusively neuronal protein synaptophysin. However, synaptophysin was found to stain also cultured astrocytes (Maienschein et al., 1999), although not in vivo astrocytes, and therefore this protein might not be suitable to decide whether neuronal synaptic vesicles prepared from cell culture preparations are contaminated by their astrocytic counterparts.

3. They criticize fluorocitric acid and D-aminoadipic acid as tools to selectively depress astrocytic metabolism and thereby to inhibit the astrocyte-neuron dialogue by astrocytic signaling molecules. We consider the publications cited by them as not really convincing. Koenig (1969) reported neuronal damage after fluorocitric acidinduced seizures following intrathecal injection to cats, rather than after $1 \mathrm{~h}$ incubation in a rodent brain slice preparation. Brown and Kretzschmar (1998) found that D-aminoadipic acid damaged dividing astrocytes; this actually supports the notion that this compound is an astrocytic poison.

4. They discuss the results of Armstrong et al. (2002) and concede that the presynaptic inhibitory effect of Bz-ATP in hippocampal CA3 neurons is mediated via adenosine A1Rs rather than by P2X7Rs. Further, they report that A1Rs were not involved in the release of glutamate, GABA, or neuronal nitric oxide production. However, A1Rs are known to exert both presynaptic and postsynaptic inhibition, and the release of the enlisted transmitters/modulators is due to an excitatory, rather than inhibitory, effect.

5. It is surprising that Díaz-Hernández et al. seemingly ignore the role of astrocytes/microglia in neurodegenerative illnesses and put emphasis only on the activation of neuronal P2X7Rs as a reason of cell death. We take an opposite standpoint and stick to the idea that astroglial/ microglial P2X7Rs are the primary targets of high ATP concentrations released from damaged neuronal and non-neuronal cells during, for example, Huntington's disease, Parkinson's disease, Alzheimer's disease, and status epilepticus. P2X7R stimulation then may cause neuroinflammation/neuronal death due to the release of cytokines, oxygen- and nitrogen-free radicals, as well as exocytotoxic molecules.
In conclusion, we can only continue to express serious doubts on the idea that functional P2X7Rs are present as a rule on all types of neurons.

\section{References}

Armstrong JN, Brust TB, Lewis RG, MacVicar BA (2002) Activation of presynaptic $\mathrm{P} 2 \mathrm{X} 7$-like receptors depresses mossy fiberCA3 synaptic transmission through p38 mitogen-activated protein kinase. J Neurosci 22:5938-5945. Medline

Brown DR, Kretzschmar HA (1998) The glio-toxic mechanism of alpha-aminoadipic acid on cultured astrocytes. J Neurocytol 27:109_ 118. CrossRef Medline

Koenig H (1969) Acute axonal dystrophy caused by fluorocitrate: the role of mitochondrial swelling. Science 164:310-312. CrossRef Medline

Maienschein V, Marxen M, Volknandt W, Zimmermann H (1999) A plethora of presynaptic proteins associated with ATPstoring organelles in cultured astrocytes. Glia 26:233-244. CrossRef Medline

\section{References}

Allgaier C, Reinhardt R, Schädlich H, Rubini P, Bauer S, Reichenbach A, Illes P (2004) Somatic and axonal effects of ATP via P2X2 but not P2X7 receptors in rat thoracolumbar sympathetic neurones. J Neurochem 90 : 359-367. CrossRef Medline

Alloisio S, Cervetto C, Passalacqua M, Barbieri R, Maura G, Nobile M, Marcoli M (2008) Functional evidence for presynaptic P2X7 receptors in adult rat cerebrocortical nerve terminals. FEBS Lett 582:3948-3953. CrossRef Medline

Amoroso F, Capece M, Rotondo A, Cangelosi D, Ferracin M, Franceschini A, Raffaghello L, Pistoia V, Varesio L, Adinolfi E (2015) The P2X7 receptor is a key modulator of the PI3K/GSK3beta/VEGF signaling network: evidence in experimental neuroblastoma. Oncogene 34:5240-5251. CrossRef Medline

Anccasi RM, Ornelas IM, Cossenza M, Persechini PM, Ventura AL (2013) ATP induces the death of developing avian retinal neurons in culture via activation of P2X7 and glutamate receptors. Purinergic Signal 9:15-29. CrossRef Medline

Anderson CM, Nedergaard M (2006) Emerging challenges of assigning $\mathrm{P} 2 \mathrm{X} 7$ receptor function and immunoreactivity in neurons. Trends Neurosci 29:257-262. CrossRef Medline

Arbeloa J, Pérez-Samartin A, Gottlieb M, Matute C (2012) P2X7 receptor blockade prevents ATP excitotoxicity in neurons and reduces brain damage after ischemia. Neurobiol Dis 45:954-961. CrossRef Medline

Armstrong JN, Brust TB, Lewis RG, MacVicar BA (2002) Activation of presynaptic P2X7-like receptors depresses mossy fiber-CA3 synaptic transmission through p38 mitogen-activated protein kinase. J Neurosci 22: 5938-5945. Medline

Atkinson L, Batten TF, Moores TS, Varoqui H, Erickson JD, Deuchars J (2004) Differential co-localisation of the P2X7 receptor subunit with vesicular glutamate transporters VGLUT1 and VGLUT2 in rat CNS. Neuroscience 123:761-768. CrossRef Medline

Brown DR, Kretzschmar HA (1998) The glio-toxic mechanism of alphaaminoadipic acid on cultured astrocytes. J Neurocytol 27:109-118. CrossRef Medline

Burnstock G, Fredholm BB, Verkhratsky A (2011) Adenosine and ATP receptors in the brain. Curr Top Med Chem 11:973-1011. CrossRef Medline

Carmo MR, Menezes AP, Nunes AC, Pliássova A, Rolo AP, Palmeira CM, Cunha RA, Canas PM, Andrade GM (2014) The P2X7 receptor antagonist Brilliant Blue $\mathrm{G}$ attenuates contralateral rotations in a rat model of Parkinsonism through a combined control of synaptotoxicity, neurotoxicity and gliosis. Neuropharmacology 81:142-152. CrossRef Medline

Cervetto C, Mazzotta MC, Frattaroli D, Alloisio S, Nobile M, Maura G, Marcoli M (2012) Calmidazolium selectively inhibits exocytotic glutamate release evoked by P2X7 receptor activation. Neurochem Int 60:768-772. CrossRef Medline

Chao CC, Chan P, Kuo CS, Gong CL, Cheng TH, Liu ZM, Shen PC, Huang CC, Leung YM (2014) Protection of differentiated neuronal NG108-15 cells from P2X7 receptor-mediated toxicity by taurine. Pharmacol Rep 66:576-584. CrossRef Medline 
Chen S, Ma Q, Krafft PR, Chen Y, Tang J, Zhang J, Zhang JH (2013) P2X7 receptor antagonism inhibits $\mathrm{p} 38$ mitogen-activated protein kinase activation and ameliorates neuronal apoptosis after subarachnoid hemorrhage in rats. Crit Care Med 41:e466-e474. CrossRef Medline

Chen X, Hu J, Jiang L, Xu S, Zheng B, Wang C, Zhang J, Wei X, Chang L, Wang Q (2014) Brilliant Blue G improves cognition in an animal model of Alzheimer's disease and inhibits amyloid-beta-induced loss of filopodia and dendrite spines in hippocampal neurons. Neuroscience 279:94101. CrossRef Medline

Cheung KK, Chan WY, Burnstock G (2005) Expression of P2X purinoceptors during rat brain development and their inhibitory role on motor axon outgrowth in neural tube explant cultures. Neuroscience 133:937945. CrossRef Medline

Cho JH, Choi IS, Jang IS (2010) P2X7 receptors enhance glutamate release in hippocampal hilar neurons. Neuroreport 21:865-870. CrossRef Medline

Codocedo JF, Godoy JA, Poblete MI, Inestrosa NC, Huidobro-Toro JP (2013) ATP induces NO production in hippocampal neurons by P2X(7) receptor activation independent of glutamate signaling. PLoS One 8:e57626. CrossRef Medline

Collo G, Neidhart S, Kawashima E, Kosco-Vilbois M, North RA, Buell G (1997) Tissue distribution of the P2X7 receptor. Neuropharmacology 36:1277-1283. CrossRef Medline

Csölle C, Baranyi M, Zsilla G, Kittel A, Gölöncser F, Illes P, Papp E, Vizi ES, Sperlágh B (2013) Neurochemical changes in the mouse hippocampus underlying the antidepressant effect of genetic deletion of $\mathrm{P} 2 \mathrm{X} 7$ receptors. PLoS One 8:e66547. CrossRef Medline

Cuadra AE, Custer EE, Bosworth EL, Lemos JR (2014) P2X7 receptors in neurohypophysial terminals: evidence for their role in arginine-vasopressin secretion. J Cell Physiol 229:333-342. CrossRef Medline

da Silva JS, Dotti CG (2002) Breaking the neuronal sphere: regulation of the actin cytoskeleton in neuritogenesis. Nat Rev Neurosci 3:694-704. CrossRef Medline

del Puerto A, Díaz-Hernández JI, Tapia M, Gómez-Villafuertes R, Benitez MJ, Zhang J, Miras-Portugal MT, Wandosell F, Díaz-Hernández M, Garrido JJ (2012) Adenylate cyclase 5 coordinates the action of ADP, P2Y1, P2Y13 and ATP-gated P2X7 receptors on axonal elongation. J Cell Sci 125:176-188. CrossRef Medline

del Puerto A, Fronzaroli-Molinieres L, Perez-Alvarez MJ, Giraud P, Carlier E, Wandosell F, Debanne D, Garrido JJ (2015) ATP-P2X7 receptor modulates axon initial segment composition and function in physiological conditions and brain injury. Cereb Cortex 25:2282-2294. CrossRef Medline

Delarasse C, Gonnord P, Galante M, Auger R, Daniel H, Motta I, Kanellopoulos JM (2009) Neural progenitor cell death is induced by extracellular ATP via ligation of P2X7 receptor. J Neurochem 109:846-857. CrossRef Medline

Deuchars SA, Atkinson L, Brooke RE, Musa H, Milligan CJ, Batten TF, Buckley NJ, Parson SH, Deuchars J (2001) Neuronal P2X7 receptors are targeted to presynaptic terminals in the central and peripheral nervous systems. J Neurosci 21:7143-7152. Medline

Díaz-Hernández JI, Gómez-Villafuertes R, León-Otegui M, HontecillasPrieto L, del Puerto A, Trejo JL, Lucas JJ, Garrido JJ, Gualix J, MirasPortugal MT, Díaz-Hernández M (2012) In vivo P2X7 inhibition reduces amyloid plaques in Alzheimer's disease through GSK3beta and secretases. Neurobiol Aging 33:1816-1828. CrossRef Medline

Díaz-Hernández M, Pintor J, Castro E, Miras-Portugal MT (2002) Colocalisation of functional nicotinic and ionotropic nucleotide receptors in isolated cholinergic synaptic terminals. Neuropharmacology 42:20-33. CrossRef Medline

Díaz-Hernández M, Sánchez-Nogueiro J, Pintor J, Miras-Portugal MT (2004) Interaction between dinucleotide and nicotinic receptors in individual cholinergic terminals. J Pharmacol Exp Ther 311:954-967. CrossRef Medline

Díaz-Hernández M, del Puerto A, Díaz-Hernández JI, Díez-Zaera M, Lucas JJ, Garrido JJ, Miras-Portugal MT (2008) Inhibition of the ATP-gated $\mathrm{P} 2 \mathrm{X} 7$ receptor promotes axonal growth and branching in cultured hippocampal neurons. J Cell Sci 121:3717-3728. CrossRef Medline

Díaz-Hernández M, Díez-Zaera M, Sánchez-Nogueiro J, Gómez-Villafuertes R, Canals JM, Alberch J, Miras-Portugal MT, Lucas JJ (2009) Altered P2X7-receptor level and function in mouse models of Huntington's disease and therapeutic efficacy of antagonist administration. FASEB J 23: 1893-1906. CrossRef Medline

Díez-Zaera M, Díaz-Hernández JI, Hernández-Álvarez E, Zimmermann H,
Díaz-Hernández M, Miras-Portugal MT (2011) Tissue-nonspecific alkaline phosphatase promotes axonal growth of hippocampal neurons. Mol Biol Cell 22:1014-1024. CrossRef Medline

Engel T, Gómez-Villafuertes R, Tanaka K, Mesuret G, Sanz-Rodriguez A, García-Huerta P, Miras-Portugal MT, Henshall DC, Díaz-Hernández M (2012) Seizure suppression and neuroprotection by targeting the purinergic P2X7 receptor during status epilepticus in mice. FASEB J 26:16161628. CrossRef Medline

Ficker C, Rozmer K, Kató E, Andó RD, Schumann L, Krügel U, Franke H, Sperlágh B, Riedel T, Illes P (2014) Astrocyte-neuron interaction in the substantia gelatinosa of the spinal cord dorsal horn via $\mathrm{P} 2 \mathrm{X} 7$ receptormediated release of glutamate and reactive oxygen species. Glia 62:16711686. CrossRef Medline

Forostyak O, Romanyuk N, Verkhratsky A, Sykova E, Dayanithi G (2013) Plasticity of calcium signaling cascades in human embryonic stem cellderived neural precursors. Stem Cells Dev 22:1506-1521. CrossRef Medline

Gandelman M, Levy M, Cassina P, Barbeito L, Beckman JS (2013) P2X7 receptor-induced death of motor neurons by a peroxynitrite/FASdependent pathway. J Neurochem 126:382-388. CrossRef Medline

García-Huerta P, Díaz-Hernández M, Delicado EG, Pimentel-Santillana M, Miras-Portugal MT, Gómez-Villafuertes R (2012) The specificity protein factor Sp1 mediates transcriptional regulation of $\mathrm{P} 2 \mathrm{X} 7$ receptors in the nervous system. J Biol Chem 287:44628-44644. CrossRef Medline

Gargett CE, Wiley JS (1997) The isoquinoline derivative KN-62 a potent antagonist of the P2Z-receptor of human lymphocytes. Br J Pharmacol 120:1483-1490. CrossRef Medline

Glaser T, de Oliveira SL, Cheffer A, Beco R, Martins P, Fornazari M, Lameu C, Junior HM, Coutinho-Silva R, Ulrich H (2014) Modulation of mouse embryonic stem cell proliferation and neural differentiation by the P2X7 receptor. PLoS One 9:e96281. CrossRef Medline

Gomez TM, Spitzer NC (1999) In vivo regulation of axon extension and pathfinding by growth-cone calcium transients. Nature 397:350-355. CrossRef Medline

Gómez-Villafuertes R, del Puerto A, Díaz-Hernández M, Bustillo D, DíazHernández JI, Huerta PG, Artalejo AR, Garrido JJ, Miras-Portugal MT (2009) $\mathrm{Ca}^{2+} /$ calmodulin-dependent kinase II signalling cascade mediates $\mathrm{P} 2 \mathrm{X} 7$ receptor-dependent inhibition of neuritogenesis in neuroblastoma cells. FEBS J 276:5307-5325. CrossRef Medline

Gómez-Villafuertes R, García-Huerta P, Díaz-Hernández JI, Miras-Portugal MT (2015) PI3K/Akt signaling pathway triggers P2X7 receptor expression as a pro-survival factor of neuroblastoma cells under limiting growth conditions. Sci Rep 5:18417. CrossRef Medline

Gonçalves JT, Schafer ST, Gage FH (2016) Adult neurogenesis in the hippocampus: from stem cells to behavior. Cell 167:897-914. CrossRef Medline

Gutiérrez-Martín Y, Bustillo D, Gómez-Villafuertes R, Sánchez-Nogueiro J, Torregrosa-Hetland C, Binz T, Gutiérrez LM, Miras-Portugal MT, Artalejo AR (2011) P2X7 receptors trigger ATP exocytosis and modify secretory vesicle dynamics in neuroblastoma cells. J Biol Chem 286: 11370-11381. CrossRef Medline

Honore P, Donnelly-Roberts D, Namovic MT, Hsieh G, Zhu CZ, Mikusa JP, Hernandez G, Zhong C, Gauvin DM, Chandran P, Harris R, Medrano AP, Carroll W, Marsh K, Sullivan JP, Faltynek CR, Jarvis MF (2006) A-740003 [N-(1-\{[(cyanoimino)(5-quinolinylamino) methyl $]$ amino $\}-$ 2,2-dimethylpropyl)-2-(3,4-dimethoxyphenyl)acetamide], a novel and selective P2X7 receptor antagonist, dose-dependently reduces neuropathic pain in the rat. J Pharmacol Exp Ther 319:1376-1385. CrossRef Medline

Ireland MF, Noakes PG, Bellingham MC (2004) P2X7-like receptor subunits enhance excitatory synaptic transmission at central synapses by presynaptic mechanisms. Neuroscience 128:269-280. CrossRef Medline

Irwin JA, Erisir A, Kwon I (2016) Oral triphenylmethane food dye analog, Brilliant Blue G, prevents neuronal loss in APPSwDI/NOS2 ${ }^{-1-}$ mouse model. Curr Alzheimer Res 13:663-677. CrossRef Medline

Jiang LH, Mackenzie AB, North RA, Surprenant A (2000) Brilliant blue G selectively blocks ATP-gated rat P2X(7) receptors. Mol Pharmacol 58:8288. Medline

Jimenez-Pacheco A, Díaz-Hernández M, Arribas-Blázquez M, SanzRodriguez A, Olivos-Oré LA, Artalejo AR, Alves M, Letavic M, MirasPortugal MT, Conroy RM, Delanty N, Farrell MA, O'Brien DF, Bhattacharya A, Engel T, Henshall DC (2016) Transient P2X7 receptor antagonism produces lasting reductions in spontaneous seizures and gli- 
osis in experimental temporal lobe epilepsy. J Neurosci 36:5920-5932. CrossRef Medline

Jun DJ, Kim J, Jung SY, Song R, Noh JH, Park YS, Ryu SH, Kim JH, Kong YY, Chung JM, Kim KT (2007) Extracellular ATP mediates necrotic cell swelling in SN4741 dopaminergic neurons through P2X7 receptors. J Biol Chem 282:37350-37358. CrossRef Medline

Khakpay R, Polster D, Köles L, Skorinkin A, Szabo B, Wirkner K, Illes P (2010) Potentiation of the glutamatergic synaptic input to rat locus coeruleus neurons by P2X7 receptors. Purinergic Signal 6:349-359. CrossRef Medline

Kim M, Spelta V, Sim J, North RA, Surprenant A (2001) Differential assembly of rat purinergic P2X7 receptor in immune cells of the brain and periphery. J Biol Chem 276:23262-23267. CrossRef Medline

Koenig H (1969) Acute axonal dystrophy caused by fluorocitrate: the role of mitochondrial swelling. Science 164:310-312. CrossRef Medline

Kukley M, Stausberg P, Adelmann G, Chessell IP, Dietrich D (2004) Ectonucleotidases and nucleoside transporters mediate activation of adenosine receptors on hippocampal mossy fibers by $\mathrm{P} 2 \mathrm{X} 7$ receptor agonist 2'-3'-O-(4-benzoylbenzoyl)-ATP. J Neurosci 24:7128-7139. CrossRef Medline

Larsson KP, Hansen AJ, Dissing S (2002) The human SH-SY5Y neuroblastoma cell-line expresses a functional P2X7 purinoceptor that modulates voltage-dependent $\mathrm{Ca}^{2+}$ channel function. J Neurochem 83:285-298. CrossRef Medline

León D, Sánchez-Nogueiro J, Marín-García P, Miras-Portugal MA (2008) Glutamate release and synapsin-I phosphorylation induced by P2X7 receptor activation in cerebellar granule neurons. Neurochem Int 52:11481159. CrossRef Medline

Lovelace MD, Gu BJ, Eamegdool SS, Weible MW 2nd, Wiley JS, Allen DG, Chan-Ling T (2015) P2X7 receptors mediate innate phagocytosis by human neural precursor cells and neuroblasts. Stem Cells 33:526-541. CrossRef Medline

Maraula G, Lana D, Coppi E, Gentile F, Mello T, Melani A, Galli A, Giovannini MG, Pedata F, Pugliese AM (2014) The selective antagonism of $\mathrm{P} 2 \mathrm{X} 7$ and $\mathrm{P} 2 \mathrm{Y} 1$ receptors prevents synaptic failure and affects cell proliferation induced by oxygen and glucose deprivation in rat dentate gyrus. PLoS One 9:e115273. CrossRef Medline

Marcoli M, Cervetto C, Paluzzi P, Guarnieri S, Alloisio S, Thellung S, Nobile M, Maura G (2008) P2X7 pre-synaptic receptors in adult rat cerebrocortical nerve terminals: a role in ATP-induced glutamate release. J Neurochem 105:2330-2342. CrossRef Medline

Marin M, Karis A, Visser P, Grosveld F, Philipsen S (1997) Transcription factor Sp1 is essential for early embryonic development but dispensable for cell growth and differentiation. Cell 89:619-628. CrossRef Medline

Messemer N, Kunert C, Grohmann M, Sobottka H, Nieber K, Zimmermann H, Franke H, Nörenberg W, Straub I, Schaefer M, Riedel T, Illes P, Rubini P (2013) P2X7 receptors at adult neural progenitor cells of the mouse subventricular zone. Neuropharmacology 73:122-137. CrossRef Medline

Metzger MW, Walser SM, Aprile-Garcia F, Dedic N, Chen A, Holsboer F, Arzt E, Wurst W, Deussing JM (2017) Genetically dissecting P2rx7 expression within the central nervous system using conditional humanized mice. Purinergic Signal 13:153-170. CrossRef Medline

Michel AD, Chambers LJ, Walter DS (2008) Negative and positive allosteric modulators of the P2X(7) receptor. Br J Pharmacol 153:737-750. CrossRef Medline

Miras-Portugal MT, Díaz-Hernández M, Giráldez L, Hervás C, GómezVillafuertes R, Sen RP, Gualix J, Pintor J (2003) P2X7 receptors in rat brain: presence in synaptic terminals and granule cells. Neurochem Res 28:1597-1605. CrossRef Medline

Moores TS, Hasdemir B, Vega-Riveroll L, Deuchars J, Parson SH (2005) Properties of presynaptic P2X7-like receptors at the neuromuscular junction. Brain Res 1034:40-50. CrossRef Medline

Nelson DW, Gregg RJ, Kort ME, Perez-Medrano A, Voight EA, Wang Y, Grayson G, Namovic MT, Donnelly-Roberts DL, Niforatos W, Honore P, Jarvis MF, Faltynek CR, Carroll WA (2006) Structure-activity relationship studies on a series of novel, substituted 1-benzyl-5-phenyltetrazole P2X7 antagonists. J Med Chem 49:3659-3666. CrossRef Medline

Nicke A, Kuan YH, Masin M, Rettinger J, Marquez-Klaka B, Bender O, Górecki DC, Murrell-Lagnado RD, Soto F (2009) A functional P2X7 splice variant with an alternative transmembrane domain 1 escapes gene inactivation in P2X7 knock-out mice. J Biol Chem 284:25813-25822. CrossRef Medline
Nishida K, Nakatani T, Ohishi A, Okuda H, Higashi Y, Matsuo T, Fujimoto S, Nagasawa K (2012) Mitochondrial dysfunction is involved in P2X7 receptor-mediated neuronal cell death. J Neurochem 122:1118-1128. CrossRef Medline

Ohishi A, Keno Y, Marumiya A, Sudo Y, Uda Y, Matsuda K, Morita Y, Furuta T, Nishida K, Nagasawa K (2016) Expression level of P2X7 receptor is a determinant of ATP-induced death of mouse cultured neurons. Neuroscience 319:35-45. CrossRef Medline

Orellano EA, Rivera OJ, Chevres M, Chorna NE, González FA (2010) Inhibition of neuronal cell death after retinoic acid-induced down-regulation of P2X7 nucleotide receptor expression. Mol Cell Biochem 337:83-99. CrossRef Medline

Papp L, Vizi ES, Sperlágh B (2007) P2X7 receptor mediated phosphorylation of p38MAP kinase in the hippocampus. Biochem Biophys Res Commun 355:568-574. CrossRef Medline

Patti L, Raiteri L, Grilli M, Parodi M, Raiteri M, Marchi M (2006) P2X(7) receptors exert a permissive role on the activation of release-enhancing presynaptic alpha7 nicotinic receptors co-existing on rat neocortex glutamatergic terminals. Neuropharmacology 50:705-713. CrossRef Medline

Peng W, Cotrina ML, Han X, Yu H, Bekar L, Blum L, Takano T, Tian GF, Goldman SA, Nedergaard M (2009) Systemic administration of an antagonist of the ATP-sensitive receptor P2X7 improves recovery after spinal cord injury. Proc Natl Acad Sci U S A 106:12489-12493. CrossRef Medline

Ridderström M, Ohlsson M (2014) Brilliant blue G treatment facilitates regeneration after optic nerve injury in the adult rat. Neuroreport 25:14051410. CrossRef Medline

Rubini P, Pagel G, Mehri S, Marquardt P, Riedel T, Illes P (2014) Functional P2X7 receptors at cultured hippocampal astrocytes but not neurons. Naunyn Schmiedebergs Arch Pharmacol 387:943-954. CrossRef Medline

Sahlender DA, Savtchouk I, Volterra A (2014) What do we know about gliotransmitter release from astrocytes? Philos Trans R Soc Lond B Biol Sci 369:20130592. CrossRef Medline

Sánchez-Nogueiro J, Marín-García P, Miras-Portugal MT (2005) Characterization of a functional P2X(7)-like receptor in cerebellar granule neurons from P2X(7) knockout mice. FEBS Lett 579:3783-3788. CrossRef Medline

Sánchez-Nogueiro J, Marín-García P, Bustillo D, Olivos-Oré LA, MirasPortugal MT, Artalejo AR (2014) Subcellular distribution and early signalling events of P2X7 receptors from mouse cerebellar granule neurons. Eur J Pharmacol 744:190-202. CrossRef Medline

Sebastián-Serrano Á, Engel T, de Diego-García L, Olivos-Oré LA, ArribasBlázquez M, Martínez-Frailes C, Pérez-Díaz C, Millán JL, Artalejo AR, Miras-Portugal MT, Henshall DC, Díaz-Hernández M (2016) Neurodevelopmental alterations and seizures developed by mouse model of infantile hypophosphatasia are associated with purinergic signalling deregulation. Hum Mol Genet 25:4143-4156. CrossRef Medline

Sim JA, Young MT, Sung HY, North RA, Surprenant A (2004) Reanalysis of P2X7 receptor expression in rodent brain. J Neurosci 24:6307-6314. CrossRef Medline

Solle M, Labasi J, Perregaux DG, Stam E, Petrushova N, Koller BH, Griffiths RJ, Gabel CA (2001) Altered cytokine production in mice lacking P2X(7) receptors. J Biol Chem 276:125-132. CrossRef Medline

Sperlágh B, Köfalvi A, Deuchars J, Atkinson L, Milligan CJ, Buckley NJ, Vizi ES (2002) Involvement of P2X7 receptors in the regulation of neurotransmitter release in the rat hippocampus. J Neurochem 81:11961211. CrossRef Medline

Surprenant A, Rassendren F, Kawashima E, North RA, Buell G (1996) The cytolytic P2Z receptor for extracellular ATP identified as a P2X receptor (P2X7). Science 272:735-738. CrossRef Medline

Thompson BA, Storm MP, Hewinson J, Hogg S, Welham MJ, MacKenzie AB (2012) A novel role for P2X7 receptor signalling in the survival of mouse embryonic stem cells. Cell Signal 24:770-778. CrossRef Medline

Tsao HK, Chiu PH, Sun SH (2013) PKC-dependent ERK phosphorylation is essential for P2X7 receptor-mediated neuronal differentiation of neural progenitor cells. Cell Death Dis 4:e751. CrossRef Medline

Verkhratsky A, Matteoli M, Parpura V, Mothet JP, Zorec R (2016) Astrocytes as secretory cells of the central nervous system: idiosyncrasies of vesicular secretion. EMBO J 35:239-257. CrossRef Medline

Virginio C, MacKenzie A, North RA, Surprenant A (1999a) Kinetics of cell lysis, dye uptake and permeability changes in cells expressing the rat P2X7 receptor. J Physiol 519:335-346. CrossRef Medline 
Virginio C, MacKenzie A, Rassendren FA, North RA, Surprenant A (1999b) Pore dilation of neuronal P2X receptor channels. Nat Neurosci 2:315321. CrossRef Medline

Wang XH, Xie X, Luo XG, Shang H, He ZY (2017) Inhibiting purinergic $\mathrm{P} 2 \mathrm{X} 7$ receptors with the antagonist brilliant blue $\mathrm{G}$ is neuroprotective in an intranigral lipopolysaccharide animal model of Parkinson's disease. Mol Med Rep 15:768-776. CrossRef Medline

Wilson HL, Wilson SA, Surprenant A, North RA (2002) Epithelial membrane proteins induce membrane blebbing and interact with the P2X7 receptor C terminus. J Biol Chem 277:34017-34023. CrossRef Medline

Wirkner K, Köfalvi A, Fischer W, Günther A, Franke H, Gröger-Arndt H, Nörenberg W, Madarász E, Vizi ES, Schneider D, Sperlágh B, Illes P
(2005) Supersensitivity of P2X receptors in cerebrocortical cell cultures after in vitro ischemia. J Neurochem 95:1421-1437. CrossRef Medline

Yu Y, Ugawa S, Ueda T, Ishida Y, Inoue K, Kyaw Nyunt A, Umemura A, Mase M, Yamada K, Shimada S (2008) Cellular localization of P2X7 receptor mRNA in the rat brain. Brain Res 1194:45-55. CrossRef Medline

Zhang PA, Xu QY, Xue L, Zheng H, Yan J, Xiao Y, Xu GY (2017) Neonatal maternal deprivation enhances presynaptic $\mathrm{P} 2 \mathrm{X} 7$ receptor transmission in insular cortex in an adult rat model of visceral hypersensitivity. CNS Neurosci Ther 23:145-154. CrossRef Medline

Zhang X, Zhang M, Laties AM, Mitchell CH (2005) Stimulation of P2X7 receptors elevates $\mathrm{Ca}^{2+}$ and kills retinal ganglion cells. Invest Ophthalmol Vis Sci 46:2183-2191. CrossRef Medline 